\title{
CONSTANTINO EL GRANDE Y DANIEL EL PROFETA. PROBLEMAS DE ICONOGRAFÍA E IDEOLOGÍA EN LA CONSTANTINOPLA CONSTANTINIANA*
}

\author{
CONSTANTINE THE GREAT AND DANIEL THE PROPHET. ICONOGRAPHIC AND IDEOLOGIC PROBLEMS \\ IN THE CONSTANTINE'S CONSTANTINOPLE
}

\author{
TEODORO CRESPO MAS \\ Universidad de Alicante
}

En su Vita Constantini, Eusebio de Cesarea escribió que, en la Constantinopla recién fundada por Constantino:

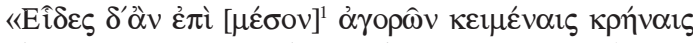

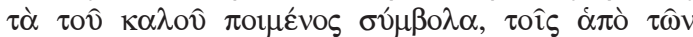

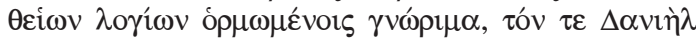

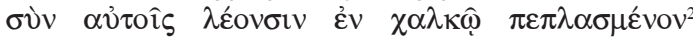

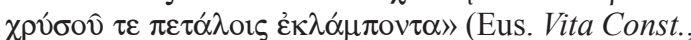
III, 49: Heikel, 1902, 98)3.
\end{abstract}

Según el obispo palestino, pues, en el centro de las plazas de la nueva capital habríamos podido contemplar unas fuentes con las efigies cristianas del Buen Pastor y del profeta Daniel con los leones, ejemplos con los que el autor pretendía demostrar la piedad cristiana del emperador. Este texto, en principio claro y no sujeto a dudas, ha sido objeto sin embargo de una controvertida atención, es más, las diversas teorías que desde la mitad del s. XX han intentado darle una explicación histórica, lo han hecho negándole cualquier posible verosimilitud.

\footnotetext{
* Quiero agradecer a los profesores Jaime Molina Vidal, Pilar González-Conde Puente, Juan Manuel Abascal, Juan Carlos Márquez, y a Barbara Iacobazzi, Alessia Palladino, Francisco Llidó y Gabriel Lara la lectura crítica y las sugerencias a las tesis que exponemos en este artículo. Los errores son nuestros.

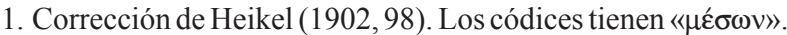

2. Otros códices tienen « $\pi \varepsilon \pi \lambda \alpha \sigma \mu \varepsilon ́ v \alpha »$ («fundidas» en bronce), conjugación que implicaría ambos «бú $\mu \beta 0 \lambda \alpha »$, versión ésta que utilizaba, por ejemplo, G.B Rossi $(1887,144)$, basándose en las $P G \mathrm{XX}, 1109$. Aquí seguiremos la versión de Heikel, de la cual citamos.

3. «En unas fuentes que hay colocadas en "medio" del ágora habrías podido contemplar las imágenes del Buen Pastor, bien conocidas por aquellos que recorren las sagradas escrituras, y la efigie de Daniel con los leones, fundida en bronce y reluciendo por las planchas de oro» (la traducción es de M. Gurruchaga para la ed. Gredos, en Eusebio de Cesarea, 1994, 305).
}

El presente artículo tiene como objetivo el análisis de este pasaje. Nuestra intención es valorar una hipótesis alternativa a las que se han formulado hasta ahora, pero con el particular de que en nuestro caso se tiende a considerar como verdadero el fragmento eusebiano. Para ello, partimos de principios teóricos y metodológicos distintos a los utilizados hasta el momento, es decir, se intenta comprender la información que nos ofrecen las fuentes a la luz del significado que podría adquirir en su contexto histórico, porque, como han puesto de relieve historiadores como M. Torelli, «uno degli errori più caratteristici di ogni ermeneutica dei contenuti della rappresentazione [...] è quello del procedere ad analisi di oggetti singoli o di dettagli iconografici isolati» (Torelli, 1997, 11) . Por otro lado, no se trata de detenernos de nuevo en la sola dimensión religiosa de la cuestión, que ha tendido a menudo a exaltar el pasaje, como ya hicieran Eusebio y la historiografía apologética posterior, como una prueba de la cristiandad del emperador. Como ha señalado C. Mango (1985, 34-36), no se trata nuevamente de retomar el interminable debate sobre la «conversión» de Constantino, sino de descubrir en qué modo le impuso a Constantinopla un carácter cristiano (o no, habría que matizar) a través de sus iniciativas arquitectónicas y, podríamos añadir por lo que aquí nos concierne, iconográficas. En este sentido, hemos creído adecuado partir del concepto de «programa iconográfico» que algunos historiadores han puesto de relieve para comprender la política cultural de los emperadores romanos (así como de las elites de otros períodos de la antigüedad), y cuya obra paradigmática parece seguir siendo aún hoy en día el Augustus und die Macht

\footnotetext{
4. Véase también, en este sentido, Zanker, 2002, especialmente los capítulos 1 y 11 .
} 


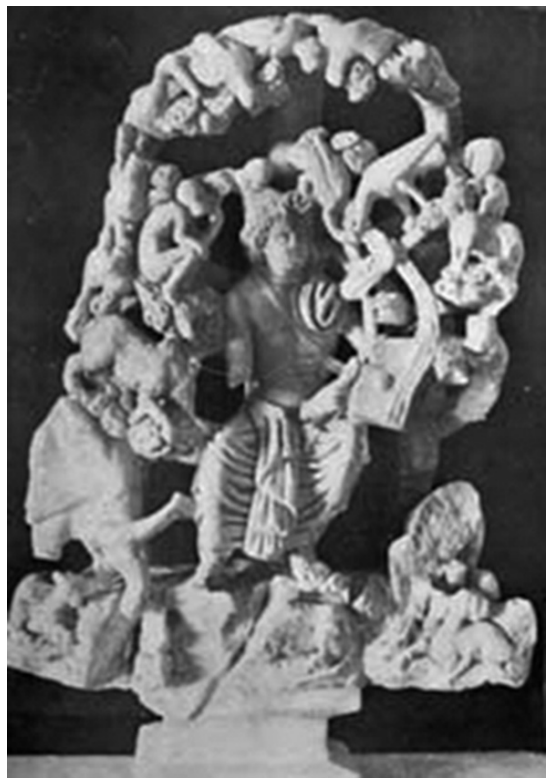

Figura 1: Orfeo de Biblos (Lauffray, 1940, 10).

der Bilder de P. Zanker (1987)5. Se ha intentado, en resumen, entender el dato como parte integrante de una ideología imperial bien articulada; la noticia eusebiana podría constituir, desde este punto de vista, una magnífica oportunidad para llevar a cabo una investigación de este tipo.

Las primeras objeciones a la verosimilitud del pasaje de Eusebio vinieron de manos de Ch. Picard (1947, 266-281) y G. Becatti ${ }^{6}$, y las hicieron partiendo de unos planteamientos que podríamos definir como histórico-artísticos y arqueológicos. Su argumento principal consistía en que Eusebio habría interpretado mal las imágenes que vio en las fuentes constantinopolitanas, sincretizando y transformando según su mentalidad cristiana el típico motivo oriental de Orfeo en el Buen Pastor y Daniel entre los leones. La prueba principal que aducían para ello era un grupo de Orfeo

5. Se trata de un método reconducible en última instancia a la influencia del historiador del arte R. Bianchi Bandinelli, y continuado por otros alumnos suyos como M. Torelli (por ejemplo, Torelli, 1997) o F. Coarelli (por ejemplo, Coarelli, 1996). Tal aproximación al estudio del arte antiguo tiende a interpretar el significado y el estilo del objeto artístico en relación con su contexto histórico, a través principalmente de la relación entre el mecenas y el artesano. Se trata, a grandes rasgos, de no considerar sistemáticamente el arte y la iconografía antiguas, máxime cuando aparecen vinculadas a las esferas del poder, desde un punto de vista puramente estético o como el fruto de la sola inspiración artística, sino de aprehender el sentido y la coherencia que éstas pueden tener en un momento histórico concreto o en el interior de una precisa ideología. Problemas y preocupaciones científicas análogas se han dado en el estudio del arte moderno; véanse por ejemplo Settis, 1978 o Ginzburg, 1981.

6. En Becatti, 1959, 889, el autor expuso esta idea, que argumentaría un año después en Becatti, 1960, 210-212. con los animales que decoraba una fuente descubierta en Biblos (Lauffray, 1940) (Fig. 1). Esta interpretación era el resultado de una evolución historiográfica que el descubrimiento de Biblos había «coronado». Con anterioridad a la interpretación de estos dos autores, el fragmento eusebiano había sido puesto en relación por Ch. Bayet (1879, 31-32) y G.B. De Rossi (1887, 143-144) con una serie de estatuillas del Buen Pastor encontradas en Grecia, en Tracia y en el Bósforo. Rossi pensaba, por ejemplo, que hubieran sido imitaciones o repeticiones de las estatuas del Buen Pastor con las que Constantino habría decorado las fuentes de Constantinopla ${ }^{7}$. Pocos años después, G. Mendel retomó el problema, y añadió la observación de que una base y un pequeño pilar formaban parte, como un conjunto integrado, de algunas de aquellas estatuas de la región de Esmirna, de Estambul y de Atenas que representaban al Buen Pastor y a Orfeo con los animales (Mendel, 1914, 412-416, $\mathrm{n}^{\circ}$ cat. $648 ; 416-420, \mathrm{n}^{\circ}$ cat. 649 y $650 ; 420-423, n^{\circ}$ cat. 651$)$. Esta constatación le hizo atribuirles un destino y una función arquitectónica idénticas, y lo llevó a suponer, siguiendo la noticia eusebiana, que estas estatuas hubieran tenido un lugar bien definido en la arquitectura de ciertas fuentes, asumiendo el rol de pequeñas cariátides que sostendrían un arquitrabe . $^{8}$

Ch. Picard, siguiendo estas indicaciones, y añadiendo el nuevo dato ofrecido por Biblos (aparecido en 1914, pero publicado solamente en 1940), desarrolló una interpretación particular del fragmento de Eusebio: en las fuentes del centro del Foro de Constantino había que ver, más que las estatuas del Buen Pastor o de Daniel entre los leones, un Orfeo entre las bestias. A estos argumentos, y en un marco historiográfico

7. Esta datación post-constantiniana, sin embargo, ha sido rechazada, y hoy se tiende a datar las estatuillas alrededor de la mitad del s. III. M. Floriani (1941, 66-67; 1946-1948, 9-12) pensaba que los tipos del Orfeo de Sabratha se habrían difundido a partir de la mitad del s. III desde un centro oriental, que en su opinión había que idenificar con Afrodisia de Caria y su escuela. También W.D. Wixom (1967, 88d), en su análisis de las esculturas del museo de Cleveland, proponía una datación alrededor de la segunda mitad del s. III, por su cercanía al arte helenístico imperial, y señalaba su origen en un centro fuertemente helenizado del oriente mediterráneo.

8. Contra esta hipótesis, M. Floriani Squarciapino sostenía que este tipo de estatuillas habrían tenido una función de candelabros, por el agujero superior que presentaban los pequeños pilares adosados en muchas de las estatuillas, candelabros que encontrarían su lugar por ejemplo en los nichos de las tumbas (Floriani Squarciapino, 1941, 61-79). Después del artículo de Picard sobre la fuente de Biblos, Floriani continuó defendiendo que estas estatuillas no tuvieron una función arquitectónica y que, si no utilizadas como candelabros, habrían sido de todos modos simples objetos ornamentales (Floriani Squarciapino, 1946-48, 9-15). Para un resumen de las diferentes teorías que se han propuesto para la función de estas estatuillas, véase Wixom, $1967,88 \mathrm{~g}$. 
general de críticas a la autenticidad de la Vita Constantini, aportaba otras pruebas como la que le señalaba A. Boulanger (1929, 108, n. 3), que había interpretado un pasaje de Marcial relacionado con un Lacus Orpheus de Roma (Mart. epigr. 10, 20, 6-8) como una probable fuente pública con hemiciclo decorada con un grupo del cantor tracio (Picard, 1947, 281). En un contexto similar, Eusebio, según Picard, habría podido confundir fácilmente la imagen de Orfeo entre los animales con las del Buen Pastor y Daniel, efigies que, como se sabía, habían sido sus herederas dóciles y directas en el arte cristiano.

Esta teoría fue ulteriormente perfeccionada por G. Becatti. Siguiendo la noticia de Eusebio según la cual la fuente habría estado situada en medio de la plaza, el autor planteaba la hipótesis de que la columna porfiria del Foro de Constantino no hubiese ocupado el centro exacto de la misma, porque su basamento monumental habría obstaculizado el tráfico de la Mese, la arteria principal de la ciudad. Su lugar, en cambio, lo habría ocupado un monumento ornamental más pequeño, la fuente de la que hablaba Eusebio. Como prueba definitiva de esta interpretación, traía a colación una ilustración de la columna historiada de Arcadio (Fig. 2) dibujada por un viajante alemán en 1575 (cuya obra fue reeditada E.H. Freshfield en el s. XIX), y en la que se podía observar el foro circular de Constantino con la columna porfiria descentrada. Pero sobre todo, a su derecha aparecían unas figuras que Becatti interpretaba como un grupo escultórico, pertenecientes en su opinión a la susodicha fuente, y en la cual creía poder reconocer un personaje que llevaba un manto y un animal que pacía a su lado, y que identificaba con Orfeo y una oveja ${ }^{9}$. En fin, los argumentos para considerar improbable la noticia eusebiana eran resumidos por el autor de la siguiente forma:

\begin{abstract}
«Sembrerebbe peraltro piuttosto singolare la decorazione di una fontana con simboli del Buon Pastore e con Daniele fra i leoni; prima di tutto perché se potremmo bene ammettere una statua del Buon Pastore nel periodo di Costantino, non avrebbe senso una raffigurazione dei soli simboli del Buon Pastore, e dovendoli immaginare come pecore isolate non potrebbero assumere un contenuto cristiano se non nella mente di Eusebio, e tanto più difficile sarebbe poi giustificare la collocazione in una fontana di un soggetto come Daniele fra i leoni. Credo pertanto che Eusebio abbia male interpretato l'ornamenazione plastica di questa fontana secondo la propria mentalità cristiana, e che probabilmente doveva trattarsi di un gruppo statuario di Orfeo circondato dagli animali, fra cui le pecore, che apparivano ad Eusebio come simboli del Buon Pastore, e i leoni forse disposti con
\end{abstract}

9. En la misma imagen, C.G. Giglioli vería erróneamente «un'ingenua e schematica veduta dall'alto nell'interno dello stesso Ippodromo con una fila di colonne una delle quali sormontata da una statua, e figure a piedi e a cavallo» (Giglioli, 1952, 28).

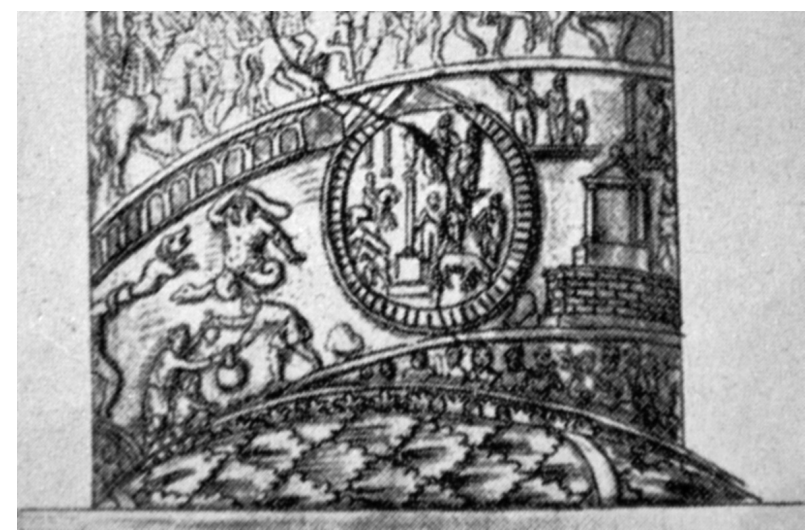

Figura 2: Fragmento de la Columna de Arcadio con la imagen del Foro de Constantino (Becatti, 1960).

una certa simmetria bilaterale da indurre a vedere nel cantore tracio inquadrato da questi animali il profeta Daniele. [...] Nella decorazione plastica della fontana del Foro di Constantino -concluía Becatti-si era scelto dunque il tema di Orfeo, che era tradizionale per questo tipo di monumento e particolarmente diffuso nell'arte tardo antica della corrente orientale» (Becatti, 1960, 211-212).

Esta teoría, basada como hemos visto en argumentos histórico-artísticos, ha mantenido su fuerza hasta hace poco, ya que diversos autores la han considerado como la hipótesis más plausible para explicar el pasaje de Eusebio que nos ocupa ${ }^{10}$.

Otro frente de objeciones al fragmento tratado ha venido de autores que, dudando también de su veracidad, la han puesto en relación con un problema diferente: Eusebio no pudo ver la estatua del Buen Pastor y de Daniel porque la política religiosa de Constantino, en un momento en el que los padres de la Iglesia estaban criticando el culto a las imágenes, no habría previsto la introducción de iconos sagrados en el mundo cristiano. J. Kollwitz (1953), por ejemplo, argumentaba que el uso de la palabra $\langle\sigma \hat{\sigma} \mu \beta 0 \lambda \alpha\rangle$ en el pasaje eusebiano era una razón válida para identificar el Buen Pastor como una figura alegórica, un símbolo puro; Th. Klauser (1965), a su vez, consideraba el pasaje altamente sospechoso en el contexto cristiano de la prohibición del uso de imágenes en el ritual. En fin, para R. Grigg $(1977,6)$ la figura del Buen Pastor descrita por Eusebio, si bien pudiese referirse a una estatua, habría sido solamente una alegoría de Jesús que habría permitido no representar directamente a Dios; de esta forma, «simbolizando» a Cristo, no se

10. Véase por ejemplo Byvanck, 1977, 34 y Barsanti, 1992, 133. A. Cameron e G. Hall (en los comentarios a Eusebius, 1999, 298) parece que seguían esta interpretación cuando afirmaban que, visto que el Buen Pastor fue un motivo compartido con los paganos, Eusebio pudo haber dado una interpretación cristiana a ciertas estatuas paganas, así como en el caso de grupos que representaban un hombre con leones. 
habría ofendido a la divinidad, lo que impedía hablar de icono en el sentido estricto del término. Desde este punto de vista, tal vez estos autores se habrían adherido gustosos a la tesis de la identificación de aquellas estatuas con Orfeo.

Como vemos, la coherencia de las tesis de Picard o de Becatti está fuera de duda, ya que sus argumentos no son infundados y en principio se adaptarían bien al contexto histórico-artístico del mundo tardo-romano. También la otra hipótesis presenta un problema argumentado, que no puede más que suscitar una duda razonable. En nuestra opinión, no obstante, existen suficientes razones para considerar como verdadero el pasaje de Eusebio si, antes de pensar en un simple error del autor como primer paso en la investigación, se le plantean los interrogantes justos y se le busca una lógica histórica ${ }^{11}$. Una primera pregunta que, por lo tanto, deberemos plantearnos (desde el momento en el que hay razones para pensar que aquellas estatuas pudieron jugar un rol bien preciso en el contexto político, ideológico y religioso de la nueva Roma de Constantino), es ésta: ¿fue casual, o más bien irrelevante, el hecho que el emperador decidiese decorar las fuentes de su Foro con las imágenes del Buen Pastor y de Daniel entre los leones?

Sin estatuas, sin embargo, el contexto no sirve para nada. Es por esto por lo que, antes de analizar su significado, hay que empezar considerando la posibilidad de que hubieran existido realmente, es decir, que Eusebio las haya podido ver de verdad. En este sentido, es necesario señalar en primer lugar que las comparaciones en las que se basaban tanto Picard como Becatti hacían referencia a pequeñas estatuas de mármol, mientras que las estatuas de las que nos hablaba Eusebio (si no las dos, sí con seguridad la de Daniel) estaban fundidas en bronce y relucían con planchas de oro. Este hecho, en primer lugar, constituiría una prueba a favor de que Eusebio fue totalmente consciente de lo que vio y escribió, visto que se fijó en detalles como éste; en segundo lugar, tal vez deberemos tener en cuenta este particular a la hora de interpretar el significado histórico de las estatuas, ya que nos estaría hablando cuando menos de su excepcionalidad y de la importancia que les habría otorgado el emperador.

En lo que respecta al dibujo de Freshfield utilizado por Becatti, una observación más atenta nos revela que, aunque se puedan considerar los personajes a la derecha de la columna de Constantino como un grupo escultórico, no se ve por qué se debería ver allí una representación de Orfeo con una oveja. En realidad, se pueden distinguir tres individuos, el de en medio más

11. Por otra parte, partimos naturalmente de la autenticidad de la Vita Constantini, de la que ya F. Winkelmann (1962) demostró, sobre los pasos de Heikel, la autoría de Eusebio. en alto que los otros dos ${ }^{12}$, y un animal no identificable en medio y abajo de los tres (¿un perro? ¿Un lobo? ¿Una oveja?). Y si quisiéramos ver, en el de la izquierda, un personaje con manto y en el animal una oveja, como hacía Becatti, tanto mejor: podríamos identificarlo con el Buen Pastor, y en consecuencia uno de los otros podría ser Daniel. O, queriendo, podríamos ver en la supuesta figura de Orfeo un Daniel vestido a lo oriental (parece llevar un gorro frigio en la cabeza) $)^{13}$, $\mathrm{y}$ en el animal un león. Sea como sea, y aparte especulaciones, parece que este «grupo escultórico» debería ser interpretado como algo diverso, pero que por ahora se nos escapa; el argumento, en cualquier caso, no nos parece que pueda servir por el momento para reforzar la tesis de Orfeo.

Sobre la teoría de la prohibición de las imágenes, hay que decir que, para todos los autores, era el nuestro uno de los pasajes más problemáticos a los que debían hacer frente, por lo que finalizaban por considerarlo no atendible o en cualquier caso no interpretable stricto sensu. Nunca se explicaba a fondo, pues, la «anomalía» que suponía. Se insistía mucho, sobre todo, en «conjurar» el icono del Buen Pastor, aquél que mayormente podía comportar una representación directa de Dios. La efigie de Daniel, por el contrario, desaparecía de su razonamiento como si hubiera sido eclipsada por la del Buen Pastor. Esta teoría, por lo tanto, no explicaría el fragmento en su totalidad. Por otra parte, hay en la obra de Eusebio un pasaje que podría hacer dudar tanto sobre si habría sabido reconocer las estatuas cuanto por el tema de la prohibición de las imágenes. Teorizando sobre el tema de la «causalidad», ponía como ejemplo las causas de las que derivaban las estatuas. Entre éstas, decía (basándose en una casuística de tipo aristotélico), se encontraban el escultor (causa eficiente), el bronce o el mármol (causa material), la forma que le imponía el artista (que hacía que la estatua asumiera su actitud determinada), y, además, indicaba la causa fundamental sin la cual la misma había podido nacer: la voluntad de rendir un honor a alguien o de hacer un pio homenaje a la divinidad (Eus., $P E$ VI, 9, 5).

Escribiendo sobre las «causas» de las estatuas, pues, el autor nos demuestra que, al menos en teoría, era capaz de poner atención a todos estos elementos

12. Que parecería estar haciendo el gesto de «adlocutio» de los emperadores (debo -y agradezco- a Alessia Palladino la observación).

13. En este sentido, la tradición oriental, diversamente de lo que sucede en la occidental, donde suele aparecer desnudo, representa a Daniel en hábitos orientales y con el gorro frigio (véanse algunos ejemplos en Firalti, 1990, 154-155, pl. 306a-c, en Nasrallah, 1961, 48-50, pl. III.3, en Tsafrir, 1989, 1739-1740, en Dalton, 1901, 55, nº 298, pl. Xb, en Wulff, 1909, 79, no 242; 94, no 288, t. IX e X, 288; 311, $\mathrm{n}^{\circ}$ 1638). Un poco más a occidente encontramos también esta representación en un relicario de Rávena, del 440-450 (Angiolini Martinelli, 1968, 81-82, no 138, tab. 138d). 
cuando veía una. Si aplicamos este hecho a la descripción concreta que el obispo nos hace de las dos estatuas de las fuentes de Constantinopla, observamos en efecto que nos indica todos estos elementos: el material con el que fueron forjadas (bronce con láminas doradas), las formas que les dio el artista (las representaciones del Buen Pastor y de Daniel con los leones), y en fin la causa principal, el motivo último por el que fueron hechas, y que en su opinión deberíamos ver en la devoción del mecenas, Constantino. Esto, pues, podría hacer dudar que Eusebio se hubiera equivocado tan burdamente en la identificación de los sujetos identificados. Por otra parte, hay que señalar que el obispo palestino no parecía ver ningún problema en el hecho de que fueran esculpidas estatuas como «pio homenaje a la divinidad». Ahora bien, ¿se refería a estatuas de divinidades paganas? ¿O consideraba también la posibilidad que estatuas con motivos cristianos e incluso que representaran a la misma divinidad pudieran ser creadas?

Procedamos ahora, prosiguiendo la argumentación, señalando un particular que Eusebio nos precisó claramente, respecto al número de las imágenes: en

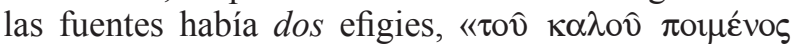

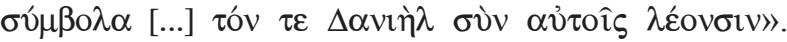
No una, por lo tanto, o quizás la otra: ambas. No se comprende pues por qué habría debido ignorar una (y cómo habría sido posible). El problema, como hemos visto, residía en la interpretación dada al término

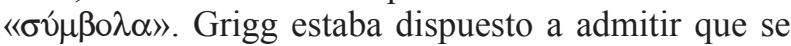
tratara de una estatua del Buen Pastor, pero entendida solamente como una alegoría de Jesús; Kollwitz, en cambio, lo consideraba un puro símbolo. Becatti, por su parte, imaginaba que las ovejas hubiesen representado simbólicamente para Eusebio al Buen Pastor, y que los posibles leones que acompañarían a Orfeo lo hubieran llevado a la su identificación con Daniel: una idea, ciertamente, cuando menos ingeniosa, pero en cualquier caso no desprovista de ciertas peripecias en la argumentación. Es por ello que nos preguntamos: ¿es posible romper de este modo la unicidad de un grupo escultórico, y hacer una operación de sincretismo «duplicado» (hacer derivar de dos estatuas una sola)? ¿Cómo se pueden extraer (y confundir) dos motivos iconográficos, o lo que es lo mismo, dos conjuntos con significado autónomo, de un sólo monumento, con un contenido asimismo concreto? Y, naturalmente, todo esto en el caso de que debiéramos imaginar una sola fuente para cada plaza, y no una por cada estatua, lo que tampoco se precisa en el texto.

Continuando con el problema de la confusión sincretista en Eusebio, hay que discutir ahora si, como sostenía Becatti, «Eusebio abbia male interpretato l'ornamentazione plastica di questa fontana secondo la propria mentalità cristiana». Desde este punto de vista, nos parece cuando menos extraño que Eusebio, uno de los autores cristianos que un mayor conocimiento tuvo de la mitología antigua (así como de la Biblia, se entiende), haya podido confundir tan fácilmente un grupo de significado tan preciso, como Orfeo entre las fieras, con las estatuas del Buen Pastor y de Daniel entre los leones. En primer lugar porque, si bien podríamos aceptar desde un punto de vista iconográfico el sincretismo entre el Buen Pastor y Orfeo, bien documentado en catacumbas como la de Domitila en Roma, no sería tan fácil hacerlo con el de Orfeo y Daniel. En efecto, y aun admitiendo que el Daniel de Constantinopla hubiera podido ir vestido según la moda oriental y con el gorro frigio (y no desnudo, como aparece a menudo en occidente), las diferencias entre ambas imágenes habrían sido tan notables que no se las habría podido confundir. Daniel es representado casi siempre de pie, normalmente con un león a cada lado (a menudo simétricamente), y las más de las veces con los brazos alzados (en posición de orante); Orfeo, en cambio (y sobre todo en las estatuillas que decorarían las fuentes, pero también en mosaicos y pinturas), aparece por lo general sentado, con un manto enganchado que le cubre hasta la cintura, circundado de múltiples y diversos animales y, sobre todo, tocando la lira: un detalle éste que, cuesta creer, Eusebio haya podido pasar por alto, ya que este elemento ocupó un espacio no banal en sus reflexiones teológicas. Es bien conocido en este sentido el pasaje en el que el autor compara el canto apaciguador del cantor tracio, que «suena los acordes de su instrumento con mano maestra», con la obra del dios cristiano que calmó las almas humanas con la doctrina divina (Eus. de laud. Const. XIV, 5), un dato que nos indicaría, claramente, el conocimiento del autor en lo que respecta a la iconografía de Orfeo. No hay duda de que si Eusebio hubiese visto un personaje tañendo la lira, no habría podido reconocer en él a nadie más que a Orfeo.

Además, en la obra del obispo de Cesarea encontramos un claro conocimiento del mito y del pensamiento de Orfeo, así como de Daniel o del Buen Pastor. En sus Praeparationes Evangelicae, donde hacía una exposición de toda la religión pagana con la evidente intención de hacerla aparecer como un error ante la revelación cristiana, el autor hace gala de un preciso -y particular- conocimiento en lo que respecta a la figura de Orfeo: parece desprenderse de sus escritos una cierta simpatía por el tipo de religiosidad practicada por el músico tracio, que ya postulaba una especie de monoteísmo rudimentario en la religión antigua (Eus. PE XIII, 12, 4-5) ${ }^{14}$. En lo que se refiere a Daniel, fue también este un frecuente motivo de reflexión para Eusebio: los numerosos

14. En otros pasos, como Eus. $P E$ II, 1, 23, 3; II, 1, 24, 2, el autor demuestra también conocer los problemas en torno a su origen, y la relación que mantuvo con el culto a Dioniso. 
comentarios que hizo a los episodios de su libro ${ }^{15}$, por ejemplo, nos demuestran el interés que le generó este profeta. Por no mencionar que el mismo autor consideraba a Daniel y al Buen Pastor, en el pasaje aquí tratado, como «bien conocidos a los que recorren las Sagradas Escrituras». El claro conocimiento que Eusebio tuvo de estos personajes, pues, no permitiría pensar que los hubiera podido confundir de forma tan burda. Y partiendo de esta evidencia, ¿sería posible inferir que hubiera sido consciente también de sus características iconográficas, hasta el punto de poder distinguirlas sin problemas? És más, si podía conocer, como había argumentado Picard, la iconografía de Orfeo, y sabemos que la de Daniel la conocía bien (puesto que era consciente que se representaba con los leones), ¿es posible pensar que las haya confundido de forma tan simple? La respuesta, desgraciadamente, no la sabemos con certeza, aunque llegados a este punto deberíamos aceptar que la hipótesis que afirma que Eusebio hubiera reconocido las estatuas es cuando menos tan válida como la que defiende lo contrario (si no más). Aceptando, pues, que el autor hubiese interpretado correctamente lo que nos refirió, estamos en condiciones de pasar a considerar si es verdad que, como afirmaba de nuevo Becatti, «non avrebbe senso una raffigurazione dei soli simboli del Buon Pastore, [...] e tanto più difficile sarebbe poi giustificare la collocazione in una fontana di un soggetto come Daniele fra i leoni».

Veamos en primer lugar qué sentido pudo haber tenido el Buen Pastor. Más allá de una prueba de la piedad cristiana del emperador, o como alegoría de Cristo, el Buen Pastor podría ser analizado también en relación con la dimensión ideológica de la monarquía personal de Constantino, por el significado que una figura como aquélla pudo contener. Ha sido E. Kitzinger quien ha hecho notar que no fue extraño que la representación del Buen Pastor asumiera la semblanza de los retratos de Alejandro Magno, que fue, como es bien sabido, el gobernante ideal y de referencia de la antigüedad. Funcionando como símbolo de la realeza, pues, toda estatua de Buen Pastor con las características de Alejandro podía configurarse como la continuación del concepto de «buen gobernante ${ }^{16}$. Desde

15. Véanse algunos ejemplos en los Fragmenta in Danielem ( $P G$ XXIV, 525-528), en Eus. DE XV (Heikel, 1913, 494496), en Eus. H.E. I, 2, 24, o en Eus. PE VI, 11, 24.

16. La idea, formulada por E. Kitzinger (Princeton lecture, 1966, que no hemos podido consultar), era citada por Wixom, 1967, 88e, que confrontaba algunos rostros del Buen Pastor con el de Alejandro. Por otra parte, en efecto, un pequeño vistazo a textos antiguos como la Ilíada (por ejemplo II, 243; V, 512; X, 406; XVI, 2), la Odisea (por ejemplo III 150; 468; IV, 23; XVIII, 68), himnos a divinidades o reyes orientales como Asurnasirpal I, Nabucodonosor II o Sargón II (véase Seux, 1976, 499, 506, 510, 530), el prólogo y el epílogo del Codigo de Hamurabi, así como la Biblia (por ejemplo Ps., 78, 71-72; Je. 23; 17, 8; 10, 21; Ez. 34; Za. 11, este punto de vista, podríamos pensar para las fuentes de Constantinopla en una estatua del Buen Pastor con la semblanza de Alejandro, que expresara para la monarquía de Constantino una idea cara a todos los emperadores de la antigüedad, la del buen gobernante. Y quizá en este sentido habría que traer a colación tal vez hechos como que Constantino se erigiese una estatua ecuestre en el Strategion de Costantinopla, lugar donde según la tradición Alejandro habría pasado revista a su ejército antes de marchar contra Persia ${ }^{17}$, que asumiera la iconografía solar según el modelo de Alejandro en la estatua que situó sobre la columna porfiria ${ }^{18}$, y que hubiera sido el primer emperador romano en asumir el título de Magno (vinculándose así al monarca macedonio), ya que podrían relacionarse con aquella idea. Habría además, en lo referente al concepto del Buen Pastor, una confirmación indirecta (aunque no por ello menos sorprendente) al hecho de que Constantino pudiera haber sido consciente de la posibilidad de esta asociación: en la De laudibus Constantini, el elogio que fue pronunciado ante él, Eusebio lo definía como el «pastor de Dios» que, en vez de inmolar animales a los dioses según la antigua usanza, guiaba a las almas de su rebaño hacia el conocimiento de Dios y de la verdadera piedad (Eus. de laud. Const. II, 5) ${ }^{19}$. La identificación de Constantino con este icono, por lo tanto, podía ser privilegiada desde todos los puntos de vista: en primer lugar, porque le permitía vincularse a toda una tradición antigua, «pagana», que equiparaba este motivo con la idea del buen gobernante, y en concreto al monarca por excelencia, Alejandro; en segundo lugar, porque este concepto no estaba en absoluto en contradicción con la nueva religión cristiana, es más, le consentía sincretizar y perpetuar la tradición bíblica que había visto en los reyes de Israel a los pastores de Dios y en Jesús al pastor de almas, al tiempo que, situándose en este filón, le permitía presentarse como el nuevo pastor del rebaño del dios cristiano.

4-17; Ev. Jo 10, 11, 14-16), nos demuestra cuán extendido fuese el uso del título de pastor de hombres para indicar la realeza, y para significar el concepto del jefe que vela, cual pastor con su ganado, por el bienestar de su pueblo.

17. Como ha sabido ver G. Pugliese Carratelli (1981, 81-91), la elección de aquel sitio para erigir una estatua que representaba a Constantino a caballo no habría sido casual, sino un modo de vincularse al soberano por excelencia de la antigüedad. En cualquier caso, hay distintas versiones sobre este hecho, habiendo otras que dicen que la estatua puesta en el Strategion fue la de Alejandro, traída de Crisópolis por Constantino (sobre esta versión, véase E. La Rocca, 1993, 557; S. Bassett, por su parte, se hace eco de las dos versiones (Bassett, 2004, 242-243). El significado ideológico de esta operación, independientemente de la versión que se acepte, sería en todo caso la misma para la monarquía de Constantino.

18. Cfr. La Rocca, 1993, 557-560.

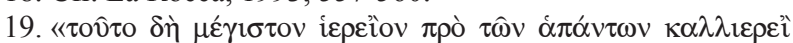

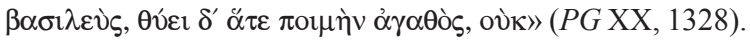


Consideremos ahora la figura de Daniel ${ }^{20}$. Se podría pensar, en un primer momento, en la dimensión soteriológica, exclusivamente religiosa, de la efigie de Daniel entre los leones; éste es en efecto el sentido que adquiere en las catacumbas y en los sarcófagos, como mensaje de salvación, de protección de Dios ante los leones (es decir, ante la muerte). Podría hacerse, sin embargo, otra lectura, más vinculada a una dimensión política. El libro veterotestamentario de Daniel, escrito en Palestina entre la mitad del s. III (el libro 2) y la mitad del siglo II a.C., para hacer frente al dominador griego y reclamar el reino de Dios (Momigliano, 1987, 41-42), es conocido, además de por las famosas escenas del pozo con los leones, que han dado forma al motivo de la iconografía cristiana, por otro aspecto de una importancia no menor: la intepretación de los sueños, esto es, de las profecías, que el profeta Daniel hizo al rey Nabucodonosor de Babilonia (Da. 2, 1-45), así como por las visiones que tuvo ( $D a$. 7). Y es aquí donde no nos parece casual la coincidencia entre la elección iconográfica del emperador y el mensaje que una imagen como aquélla pudo expresar. Es aquí donde, antes de lanzarse apresuradamente a identificar a Daniel con Orfeo, haría falta preguntarse: ifue la elección del motivo de Daniel por Constantino arbitraria, o dictada únicamente por su supuesta piedad cristiana? O en otros términos: ¿fue Constantino consciente del potencial ideológico que aquella figura tenía para la legitimación de su poder imperial? Llegados a este punto, el lector habrá advertido ya la importancia que podía comportar una representación de aquella imagen: el libro de Daniel, en efecto, contiene las profecías relativas a la sucesión de los imperios en la antigüedad, el motivo de la «translatio imperii», y para el caso que aquí nos ocupa profetizaba el imperio eterno de Dios que estaba por venir. El tema de la sucesión de los imperios fue una cuestión que circuló abundantemente en la literatura del mundo romano, no sólo de época republicana, sino también en época imperial, y especialmente en los ambientes doctos cristianos ${ }^{21}$. Formado por teorías fácilmente maleables, de las que cada autor hizo un uso diverso según las necesidades históricas de su época o su grupo social, en el caso concreto de Daniel se hacía referencia a un reino eterno de Dios que habría venido después de la caída de cuatro imperios, identificados o bien con cuatro metales o bien con cuatro bestias. Y las consecuencias que estas profecías podían comportar para el primer emperador cristiano de la historia son evidentes: Constantino podía aparecer, cuando menos, como la materialización de aquel imperio providencial querido por Dios. Ahora bien:

20. Sobre la figura de Daniel véase en general Leclercq, 1920, Minasi, 2000, Wacker, 1954, Daniélou, 1957 y Cassin, 1951. Sobre los orígenes iconográficos del motivo, Déonna, 1948; 1949, y Grossett, 1953.

21. Véase al respecto Swain, 1940, Momigliano, 1980, Flusser, 1972, Gascó La Calle, 1981, Simonetti, 1986, Delcor, 1986 y Pavan, 1986. ¿pudo el monarca haber ignorado o pasado por alto un hecho de una relevancia tan extraordinaria?

No existen, desgraciadamente, referencias explícitas en los monumentos o en los escritos atribuidos a Constantino que hagan pensar que el emperador hubiese podido mostrar un interés especial por las profecías de Daniel, pero tenemos en cambio una fuente indirecta (aunque no tanto) que pone en relación justamente un pasaje fundamental de las profecías de Daniel y la dinastía del emperador: Eusebio. Es el obispo de Cesarea, otra vez, quien nos ofrece una serie de datos preciosos para poder interpretar el sentido que pudo tener la efigie de Daniel en Constantinopla: de nuevo en el De laudibus Constantini, el panegírico que leyera en ocasión de los «tricennalia» de Costantino, Eusebio identificaba su reino con una frase extraída del libro de Daniel, y cuyas indudables implicaciones providenciales hablaban por sí solas:

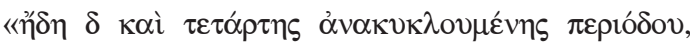

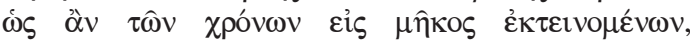

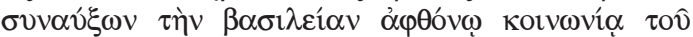

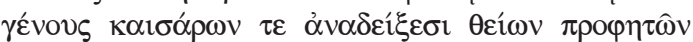

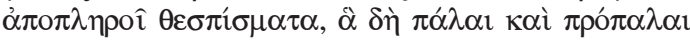

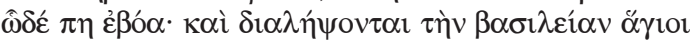

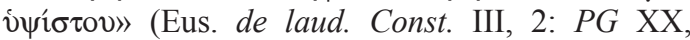
$1328-1329)^{22}$.

«I «santi dell’Altissimo» sono ormai, nella storia della salvezza umana, i Costantinidi», escribió S. Calderone, que comprendió bien cómo este pasaje daba una dimensión sagrada a la monarquía de Constantino ${ }^{23}$. También P. Maraval, en el comentario a este texto (Eusèbe de Césarée, 2001, 94, n. 1), ha visto cómo la aplicación a la dinastía constantiniana de este pasaje del libro de Daniel $(D a .7,18)$ era audaz, ya que el príncipe hereditario recibía así una justificación bíblica ${ }^{24}$.

22. «Et alors que déjà commence la quatrième période, parce que le temps s'est prolongé, il fait s'accroître sa royauté par l'association généreuse de sa famille et la proclamation de Césars; il accomplit ainsi les oracles des divins prophètes qui, autrefois, il y a bien longtemps, ont proclamé: «Et les saints du Très-Haut recevront la royauté» (trad. de P. Maraval en Eusèbe de Césarée, 2001, 93-94. Traducción inglesa en Drake, 1976, 87. Véase también, para la interpretación de la oración eusebiana, Calderone, 1985, 1-26).

23. Calderone, 1972, 234. Véase también, en este sentido, Calderone, 1988, 52-53.

24. G. Podskalsky ha observado, a su vez, cómo Eusebio, con la finalidad de ver en Roma la posibilidad del cumplimiento de la misión universal de los cristianos, no vaciló en utilizar las profecías de Daniel para ver en el reino de Constantino la materialización de las profecías bíblicas, la realización del imperio eterno de Dios (Podskalsky, 1984, 439-450). Igualmente P. Piccini, quien, trayendo a colación esta cita del libro de Daniele en el panegírico eusebiano, ha visto que

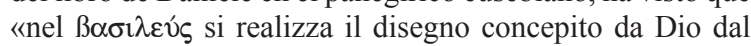
più remoto dei tempi, quello dell'impero romano-cristiano» (Piccini, 1993, 773). También J.M. Candau ha remarcado cómo en el ánimo del fundador de la nueva historiografía 
En obras anteriores (señalaba también Maraval), como en la Demonstratio Evangelica (Eus. DE XV, 5), el obispo palestino había dado interpretaciones diversas de las profecías de Daniel, según las cuales aquellos que hubieran recibido el reino de Dios habrían sido los herederos de Dios y los coherederos de Cristo, aquellos a los que les había sido prometido el reino de los cielos que se habría establecido después los cuatro reinos vistos por el profeta. Y estos cuatro reinos, había escrito Eusebio en sus Praeparationes Evangelicae, había que identificarlos con el de los babilonios (oro), el de los persas (plata), el de los macedonios (bronce) y el de los romanos (hierro) (Eus. PE VI, 11, 24). No hay duda, por lo tanto, de que en la teología eusebiana el imperio de Constantino debía representar la superación del imperio de hierro de los romanos, y el advenimiento del reino prometido, el imperio cristiano.

Daniel $(D a 7,17-18)$ había interpretado las cuatro bestias del sueño como cuatro reyes que aparecerían sobre la tierra, después de los cuales recibirían el reino los santos del altísimo para poseerlo por toda la eternidad. La trascendencia de estos pasajes bíblicos es notable, y dificilmente escapa la potencialidad que podían adquirir desde un punto de vista político, y en particular para el régimen constantiniano: presentándose como el resultado de una historia providencial, el imperio de Constantino aparecía como la cristalización del reino eterno de los santos, y quedaba legitimado a través de la voluntad divina (una monarquía, no hay que olvidarlo, que se había formado con la usurpación del poder a los otros tetrarcas, y por lo tanto necesitada de justificación). Recapitulemos, pues: hemos visto, por una parte, que según una constatación visual de Eusebio, Constantino puso las estatuas del Buen Pastor y de Daniel entre los leones en Constantinopla; hemos visto, por otra parte, la interpretación «subjetiva», derivada de sus concepciones ideológicoreligiosas, que el obispo palestino hizo de un pasaje del libro de Daniel aplicado a la dinastía de Constantino. A través de la teología política de Eusebio ${ }^{25}$, por lo tanto, podemos encontrar posibles claves interpretativas a un dato «objetivo», referido a la política iconográfica de Constantino y transmitido por la misma fuente. Y llegados a este punto la conclusión parecería obligada: Constantino hizo erigir en las fuentes aquellas dos estatuas con obvias intenciones propagandísticas e ideológicas. Con el Buen Pastor hacía converger en sí mismo el concepto de buen gobernante y se presentaba como el nuevo pastor de Dios, y con Daniel ponía fundamentos providenciales y una fuente de

eclesiástica, Eusebio, este tipo de historias debían hacer ver que desde el inicio de los tiempos Dios había enderezado el curso de los acontecimientos hasta llegar con Constantino a una nueva fase de la historia romana, marcada por la llegada del imperio cristiano (Candau Morón, 1990, 191-192).

25. Sobre Eusebio como artífice de una teología política del imperio de Constantino, véase Calderone, 1972; 1985; 1988 y Farina, 1966. carácter divino a la dinastía que fundaba. La lógica de esta hipótesis, que sitúa coherentemente el pasaje de Eusebio en un contexto histórico-político bien preciso, encontrándole así una justificación, bastaría por sí misma para cerrar cualquier discusión sobre el problema, visto que, hasta ahora, es la que una mejor comprensión ofrece de los datos disponibles. Queda, sin embargo, el problema de saber si el emperador pudo ser consciente de la relevancia de estos iconos y, sobre todo, si los pudo haber insertado en su ideología imperial. Con el dato objetivo de las estatuas en las fuentes, y con el uso teológico-político que Eusebio hizo de las mismas en sus escritos, haría falta probar solamente que también el emperador pudo haber sido tan consciente del sentido que podían entrañar hasta el punto de haberlas podido utilizar iconográficamente. Veamos ahora si podríamos demostrar esta aserción.

Aunque el panegírico eusebiano fue leído en una fecha posterior a la construcción de las fuentes en Constantinopla (que hay que situar entre la fundación y la inauguración de la ciudad, entre el 324 y el 330), sabemos con toda seguridad que Constantino escuchó el panegírico eusebiano (Drake, 1975, 347-356). Podríamos pensar, pues, que al menos para esta fecha habría podido ser consciente de este pasaje, y podríamos incluso hipotetizar que hubiera sabido identificarlo y ser consciente de sus implicaciones. La pregunta que habría que hacerse, además, sería la de saber si antes de esta fecha pudo haber conocido las profecías de Daniel, y poder determinar que la elección iconográfica fue plenamente consciente de lo que podía conllevar. Desde este punto de vista, y si hacemos caso a Eusebio, Constantino, después de la famosa visión celeste de Ponte Milvio, «consideró perentorio dedicarse a la lectura de los libros sagrados» (Eus. Vita Const. I, $32,3)^{26}$. Por otra parte, sabemos que encargó a Eusebio Biblias para las nuevas iglesias de Constantinopla (Eus. Vita Const. IV, 36). Estas noticias confirmarían, en principio, que Constantino debió conocer bien las Sagradas Escrituras y así lo ha señalado también $\mathrm{S}$. Calderone, cuando afirmaba que «Costantino, teste Eusebio, leggeva spesso la Bibbia» (Calderone, 1972, 255). En cualquier caso, el dato definitivo nos lo aportaría la Oratio ad Sanctorum coetum escrita por el emperador mismo inmediatamente después de la victoria sobre Licinio: en ella, Constantino comentaba el libro de Daniel, a quien definía como aquél que predijo los acontecimientos futuros, y fijaba su atención en el episodio en el que Daniel era salvado de los leones por la Providencia de Cristo, al que alababa con ambas manos alzadas, mientras los leones estaban en posición sumisa, como postrados a sus pasos en acto de homenaje (Const., Or. ad Sanct., XVII).

26. Citamos de Eusebio de Cesarea, 1994, 173-174. Sobre el conocimiento que el emperador tuvo de la Biblia, cfr. también Eus. Vita Const. IV, 17; 29. 


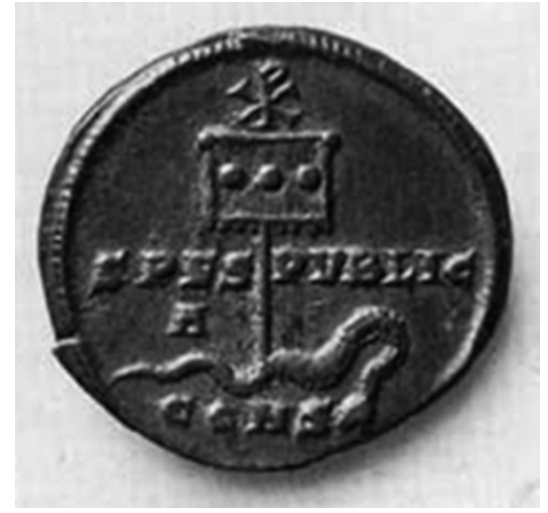

Figura 3: Acuñación constantiniana con la representación del lábaro matando a la serpiente (Kent, 1978, pl. 163 f. 649).

Constantino, pues, leía a menudo la Biblia, y conocía bien el libro de Daniel. Con estos datos, faltaría únicamente saber si el emperador fue propenso a utilizar los contenidos bíblicos con fines ideológicos y propagandísticos. Un ejemplo en este sentido, referido a un motivo muy conocido de la Biblia, podría ofrecernos una prueba colateral. En la Vita Constantini III, 3 leemos que Constantino hizo colocar un cuadro en el vestíbulo del palacio imperial; bajo sus pies y los de sus dos hijos (Constantino II e Constancio II) había una bestia en forma de dragón, herida por un dardo en el vientre y lanzado a los abismos del mar. Con esta pintura el emperador, como señalaba acertadamente Eusebio (confrontando el motivo con el pasaje de $I s .27,1$ ), traducía en imágenes las palabras de los profetas (Eus., Vita. Const. III, 3). En lo que se refiere a la serpiente, hay que ver en ella a Licinio, aquella fiera enemiga y hostil que, según las palabras del obispo, había perseguido a la Iglesia de Dios con impía tiranía, interpretación que derivaba también de la carta que el emperador envió a todos los obispos del Imperio hacía el otoño del 324 (Eus., Vita Const. II, 46) ${ }^{27}$. Además, fue éste el tema que Constantino hizo cuñar en las monedas de la ceca de Costantinopla, en tipos en los que una lanza con el lábaro arriba aparecía atravesando la serpientedragón (Fig. 3), y en la cual había que ver sea a Licinio sea al paganismo derrotados (Maurice, 1908-1912, vol. I, 103, pl. IX, 2; vol. II, 506, pl. XV, 7; Alföldi, 1948, 85). Parece evidente, como por otra parte señalaba Eusebio, que Constantino se hubiese inspirado en los episodios bíblicos, por otra parte recurrentes, para realizar esta pintura (y en este sentido podría ser sintomático que también Daniel se hubiese enfrentado y matado al dragón Bel de Babilonia (Da. 14, 27). Todo esto, en

27. Así es interpretado también por L. Tartaglia en Eusebio di Cesarea, 1984, 105, n. 75, y por Alföldi, 1948, 84-85. C. Mango añade además que la referencia a los abismos del mar, que en su opinión Eusebio toma de Ez. 32, 2 para unirlo al fragmento de Isaias, se referiría al hecho de que la derrota final de Licinio tuvo lugar en el Helesponto y en las orillas de la Propóntide (Mango, 1959, 22-24) resumidas cuentas, nos estaría indicando no sólo el conocimiento que Constantino tuvo de la Biblia, sino también que estuvo dispuesto a utilizar algunos de sus temas con fines de propaganda política.

No hay razón por lo tanto para dudar de que, más allá de la teología política elaborada por Eusebio, Constantino hubiese sido consciente y predispuesto a utilizar las profecías de Daniel para sus fines ideológicos, tal como había hecho con el motivo del asesinato del dragón. Y la confirmación a este hecho podríamos tenerla en el motivo de las fuentes que el emperador hizo erigir en las plazas de Constantinopla; la noticia de Eusebio, pues, no sólo habría que considerarla cierta, sino que supondría una información preciosa para comprender los aspectos ideológico-religiosos de la monarquía de Constantino. La legitimación divina que las estatuas del Buen Pastor y de Daniel ofrecían a los fundamentos del poder imperial, a su carácter providencial, no podía ciertamente habérsele escapado al emperador. Y si sobre la consistencia de esta hipótesis no parece que pueda haber dudas, existiría aún la posibilidad de definir mayormente el rol que una estatua como la de Daniel pudo jugar en el contexto de la «Nueva Roma».

Recientemente, S. Bassett $(2004,68-77)$ ha llevado a cabo una tentativa de reconstrucción de un posible programa iconográfico de Constantinopla, derivado de la estatuaria «pagana» que Constantino utilizó en la nueva capital, y que en su opinión ilustraría el tema de la continuidad romana en toda la ciudad, y el vínculo entre la vieja y la nueva Roma. El autor ha trazado un hilo hipotético que, a través de ciertos eventos míticos e históricos representados en el Foro de Constantino, uniría el pasado remoto de Roma con el de Constantinopla, una selección de temas que estaría gobernada por dos elementos integrados: realeza e historia. Las estatuas del Foro circular dedicado al emperador ilustrarían la naturaleza de su persona y de su poder, uniendo el presente constantiniano con la historia épica de la edad heroica. La columna en el centro compendiaba el tema del rey helenístico: hecha de pórfido, el mármol de los emperadores, tenía en la cima la estatua de Constantino radiado. El Paladio, traído de Roma por el emperador, garantizaba en su ciudad el destino de Troya y la permanencia de Roma. Las estatuas de bronce de Paris, Hera, Afrodita, Atenea y Tetis formaban un conjunto que representaba el juicio de Paris, es decir, las causas de la destrucción de Troya y el consiguiente acaecimiento de la gloria de Roma. El pasado de Constantinopla, por lo tanto, formaba una unidad con el suceso de Troya y en consecuencia de Roma, a través del Paladio ${ }^{28}$. También

28. G. Dagron, en este sentido, había advertido ya que el hecho de que Constantino se trajese de Roma el paladio constituía un modo de insistir en la romanidad de Constantinopla, y de establecer un lazo entre los destinos de las dos ciudades (G. Dagron, 1974, 30). 
las decoraciones escultóricas del Hipódromo, de los Baños de Zeuxipo, del Augusteion, del Strategion, etc., incidían asimismo en la idea de continuidad e identificación con Roma, lo que tenía su reflejo también en sus transformaciones jurídico-institucionales ${ }^{29}$. Todos los grupos escultóricos, en resumen, concurrían a construir la visión del pasado constantinopolitano y, además, Bassett señalaba también un elemento que consideramos aquí fundamental: en su opinión, se quería establecer la identidad de Constantinopla en la jerarquía urbana de los imperios, de forma coherente con los métodos de la tradición historiográfica y retórica grecorromana (Bassett, 2004, 76).

Este último argumento ha sido agudamente analizado por otro autor, que a la explicación geopolítica de la fundación de Constantinopla ha añadido la importancia de su dimensión simbólica e ideológica. S. Calderone (1993, 724-727) ha sabido ver cómo el miedo a la idea del carácter cíclico del subseguirse de los imperios y del traspaso de la primacia imperial habría jugado un rol no banal en la decisión constantiniana de volver a fundar la capital del Imperio, y cómo ésta respondería al concepto de «renacimiento» y «renovación» de la oikouméne imperial que Constantino había expresado en la Oratio ad sanctorum coetum (del año 325$)^{30}$. Así, la unificación política y religiosa por y en la figura del emperador había tenido como objetivo el renacimiento del mundo, y en este contexto:

«il significato profondo dell'idea costantiniana di una «seconda Roma» fu strettamente annodato con l'ideologia cristiana della «rinascita», della «seconda nascita», assunta tout court al ruolo di ideologia politica. [...] Una Roma «seconda» nel Tempo genetico, una Roma nuova, giovane, veramente vé $\alpha$, che

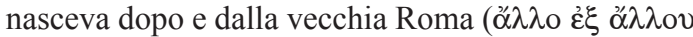
$\gamma(v o ́ \mu \varepsilon v o v)$, una Roma la cui rinascita segnava un ciclo nuovo della vicenda eterna del nomen Romanum

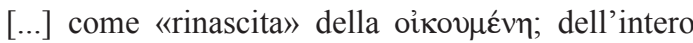
mondo romano, dunque, inteso globalmente come unitaria realtà politico-religiosa, di cui egli, Costantino, si dichiarava, ricordiamolo con Eusebio, kotvòs

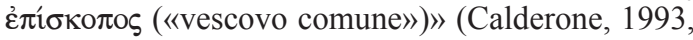
743).

Constantino, según Calderone, hizo renacer a Roma en otro lugar, y la fórmula «segunda Roma» se configuraba así como la solución ideológica de las

29. Es bien sabido, desde este punto de vista, que Constantinopla fue hecha a imagen y semejanza de Roma: dividida en catorce regiones, con siete colinas, con los mismos derechos, con senado, etc. Véase a propósito Dagron, 1974, 46-47 y Janin, 1950, 29-30.

30. En este sentido es de recordar también el brillante análisis que A. Schiavone hizo del Elogio di Roma de Elio Arístides (en el primer capítulo de Schiavone 1998), en el que desvelaba una visión optimista del Imperio que, sin embargo, escondía los miedos de un cíclico decaer de los imperios. contradicciones del pensamiento antiguo respecto al destino de Roma. La vieja Roma concluía su ciclo orgánico, y Constantinopla se convertía así en representación de la primera, pero ahora segunda y nueva; podríamos decir que se superaba, pues, aquella Roma «de hierro» que Eusebio había identificado en la profecía de Daniel.

Hemos visto, con Bassett, que el significado de la estatuaria «pagana» en Constantinopla tendía a vincularla y a hacerla heredera de todo el pasado antiguo, de la gloria y los destinos de Troya-Roma. Con todo, pensamos que el análisis de este autor quedaba incompleto, ya que descuidaba el rol que pudo haber jugado la iconografía cristiana en un discurso ideológico más global ${ }^{31}$. Calderone, por su parte, ha demostrado cómo la fundación de Constantinopla respondía al deseo de derrotar los peligros cíclicos de la sucesión de los imperios, por lo que el concepto de renacimiento cristiano asumía un rol fundamental. En este sentido, el sentido que pudieron tener las efigies del Buen $\mathrm{Pa}$ stor y Daniel entre los leones se revela ahora evidente, desde una perspectiva providencial, y si imaginamos, como había hecho Becatti, que la fuente con las estatuas hubiera estado en el centro justo del Foro de Constantino, al lado de la estatua radiada sobre la columna porfiria, la conclusión parece obvia: Constantino, como buen pastor de Dios, tendía una mirada hacia el futuro, hacia el reino eterno profetizado por Daniel. Del mismo modo que Augusto, que con el programa iconográfico de su Foro se había hecho depositario del pasado glorioso de Roma ${ }^{32}$, y en los Ludi Saecularis había proclamado una nueva edad de oro, también así Constantino se presentaba, en su Foro de su ciudad, como el nudo entre dos momentos históricos, como el punto de llegada de la gloriosa historia del imperio romano, y el punto de partida del nuevo imperio anunciado por el dios de la Biblia. En el centro del aparato decorativo del Foro, la estatua de Daniel entre los leones, fundida en bronce y quizas no por casualidad exaltada con relucientes planchas de oro, expresaba por lo tanto aquí un mensaje bien calculado.

Sólo con Constantino como punto cardinal entre dos épocas históricas, como centro articulador, se pueden entender perfectamente todas aquellas aparentes contradicciones que a menudo se han atribuido a su figura y a su ciudad. Se comprenderían, por ejemplo, hechos como que el emperador hubiera interpretado, en su Oratio ad Sanctorum Coetum, pasajes de los Oracula

31. Al lado de aquellas estatuas «paganas», en efecto, las fuentes nos hablan también de los elementos cristianos con los que Constantino adornó su ciudad. Es conocida la noticia de que el emperador hizo meter un fragmento de madera perteneciente a la vera cruz en la estatua que puso en su Foro (así como diversas reliquias de santos), la cruz que había encima del globo que la estatua tenía en la mano, o los retratos de los primeros obispos de Constantinopla (Janin, 1950, 68-69, 82-83).

32. Véase al respecto Zanker, 1992, 232-254. 
Sibyllina y un pasaje de la cuarta égloga de Virgilio como profecías de la venida de Cristo $^{33}$, vinculando así el esplendor del pasado romano con los nuevos tiempos, tendiéndole un hilo y haciéndose su heredero. Pero también, como ha puesto de relieve G. Dagron:

«Au demeurant, il ne s'agit pas tant de christianisme et de paganisme que du Constantin païen et du Constantin chrétien, car Philostorge nous avertit [...] que c'est Constantin qu'on adorait, que c'est devant lui qu'on se prosternait; en lui prennent une unité les rites d'origine religieuse diverse qui président à la fondation; les reliques chrétiennes et les symboles païens sont réunis dans sa statue; en lui n'existent pas les oppositions et les exclusives que l'histoire moderne croit reconnaître entre les religions: elles ne sont ici que des garanties cumulées. [...] C'est Constantin qui fait l'unité de ces destins, comme sa statue fait l'unité des cérémonies de 330, comme sa personne et son nom fixent la place institutionnelle de la nouvelle ville. Constantinople est dédiée à Constantin, c'est-à-dire, par lui, à l'Empire nouveau qu'il représente déjà ou tend à représenter: roman, oriental, et bientôt chrétien» (Dagron, 1974, 42).

No quedaría ya, para concluir, más que establecer una última relación, vinculada esta vez al recorrido de la pompa triunfal imperial ${ }^{34}$. En este sentido, el Foro de Constantino, como punto obligado de acceso a la «vieja» ciudad, y sobre todo al palacio imperial, fue un paso obligado de la misma. Por aquí pasaba la arteria principal de Constantinopla, es decir, la Mese, que ligaba el Foro con la entrada del palacio imperial, la Chalké, a través de un porticado conocido como la Regia, parte final de la vía triunfal (Mango, 1959, 7879). Ahora bien, si el Foro de Constantino contenía las estatuas del Buen Pastor y de Daniel, hemos visto también cómo en el vestíbulo imperial Constantino había hecho poner una pintura que lo representaba a él y a sus hijos matando a la serpiente enemiga de la Iglesia. Relacionando, pues, estas noticias, nos encontraremos de frente a dos datos que no parecen ser casuales: la vía triunfal, expresión del emperador victorioso, podía articular así un mensaje iconográfico-propagandístico bien preciso y coherente. Un mensaje globalizador que, sintetizando, quizás podríamos «leer» así: el pastor y paladino de Dios, Constantino, culminación gloriosa del pasado romano, que ha derrotado a la serpiente enemiga del cristianismo Licinio, y se ha encaminado a guiar el imperio hacia el conocimiento de la verdadera fe, encarna ahora el imperio eterno anunciado por Dios en el libro de Daniel, asociando al poder a su dinastía en la Nueva Roma por él fundada, y cumpliendo así con los versos de la profecía: que «los santos del altísimo recibirán el reino y lo poseerán por siempre, eternamente». Una idea que, en cualquier

33. Const., Oratio ad Sanctorum Coetum XVIII; XIX, 3 (cfr. Pizzani, 1993, 791-822, y Cristofoli, 2005, 59-62).

34. Véase al respecto Dagron, 1974, 100-102. caso, se hallaba ya implícita en las palabras que el emperador escribió a los obispos del imperio en el otoño del $324^{35}$, es decir, el año de la victoria de Crisópolis, de la fundación de Constantinopla, y de la asociación de su segundo hijo al trono:

«ahora $[. .$.$] se ha restituido la libertad y aquel dra-$ gón ha sido expulsado del gobierno del estado, gracias a la providencia del Omnipotente y a nuestro propio ministerio ${ }^{36}$.

«Va sottolineato con forza - podríamos concluir con M. Menichetti- che la prospettiva adottata nella presente ricerca, anche in ragione della documentazione, di quella disponibile e di quella purtroppo che non lo è più, non corrisponde ad altro che ad un'ipotesi, come tale del resto sono classificate tutte le verità scientifiche secondo l'epistemologia popperiana; l'importante, comunque, è verificare se talune di queste ipotesi possano rendere ragione più di altre di quanti più fatti possibili e delle loro reciproche relazione» (Menichetti, 1994, 126-127). Como hemos visto con el desarrollo de nuestra teoría, las conclusiones que derivan del planteamiento teórico-metodológico del que hemos partido respecto a los otros no son en absoluto banales. Aun constituyendo una hipótesis (a falta de pruebas más concluyentes), pero con, al menos, las mismas probabilidades de estar en lo cierto que las otras teorías propuestas, una cosa, sin embargo, creemos haber demostrado: la realidad histórica a la que hace referencia el pasaje de Eusebio aquí discutido tendría un sentido pleno en el contexto de la Constantinopla constantiniana (lo que no sucedería con una estatua de Orfeo calmando a las fieras). Las estatuas del Buen Pastor y de Daniel entre los leones no sólo no se desvelarían como incoherentes en la Nueva Roma, sino que se nos aparecerían en cambio como unos elementos clave de una «jaula semántica» ${ }^{37}$ urbana más amplia, fruto de una precisa elección programática tendente a articular y a legitimar ideológicamente el poder imperial. Además, si nuestra tesis llegara a ser confirmada, nos encontraríamos tal vez ante un elemento de una importancia mucho mayor: estaríamos ante un dato crucial para comprender no sólo las motivaciones ideológicas que subyacieron a la fundación de Constantinopla, sino, desde un punto de vista más general, también ante las que sustentaron la monarquía personal inaugurada por Constantino.

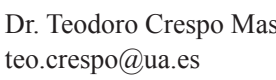

35. Sobre la datación de la carta, cfr. Dörries, 1954, 55 (cuya tesis sigue L. Tartaglia, en Eusebio di Cesarea, 1984, 105, n. 74, y M. Gurruchaga en Eusebio de Cesarea, 1994, 238, n. 65).

36. Eus., Vita Const. II, 46, 2; citamos de la traducción Eusebio de Cesarea, 1994, 238

37. El concepto se encuentra en Torelli, 1997, 93. 


\section{BIBLIOGRAFÍA}

ALFÖLDI, A., 1948: The conversion of Constantine and pagan Rome, Oxford.

ANGIOlini MARTinelli, P., 1968: «Corpus» della scultura paleocristiana, bizantina ed altomedievale di Ravenna, I, Roma.

BARSANTI, C., 1992: «Costantinopoli: testimonianze archeologiche di età costantiniana», en G. Bonamente y F. Fusco, Costantino il Grande. Dall'antichità all'umanesimo. Colloquio sul Cristianesimo nel mondo antico (Macerata 18-20 Dicembre 1990), t. I, 115-150, Macerata.

BASSETT, S., 2004: The Urban Image of Late Antique Constantinople, Cambridge.

BAYET, Ch., 1879: Recherches pour servir à l'histoire de la peinture et de la sculpture chrétiennes en Orient avant la querelle des iconoclastes (Bibliothèque des écoles françaises d'Athènes et de Rome 10), Paris.

BeCATti, G., 1959: «Constantinopoli», en Enciclopedia dell'Arte Antica, 880-914, Roma.

BECATTI, G., 1960: La colonna coclide istoriata, Roma.

Boulanger, A., 1929: Orphée. Raports de l'orphisme et du christianisme, Paris.

ByvanCK, A.W., 1977: L'Art de Constantinople, Leiden.

CALDERONE, S., 1972: «Teologia politica, successione dinastica e consecratio in età costantiniana», en AA.VV.: Le Culte des souverains dans l'Empire romain, Entretiens de la Fondation Hardt X, 215-260, Genève.

CALDERONE, S., 1985: «Eusebio e l'ideologia imperiale» en Giuffrida, C. y Mazza, M. (eds.): Le trasformazioni della cultura nella tarda antichità, Atti del Convegno tenuto a Catania, Università degli Studi (27 sett.-2 ott. 1982), 1-26, Roma.

CAlderone, S., 1988: «Il pensiero politico di Eusebio di Cesarea», en AA.VV., I cristiani e l'impero nel I secolo. Atti del Colloquio sul Cristianesimo nel mondo antico, Macerata 17-18 dicembre 1987, Publicazioni della Facoltà di Lettere e Filosofia dell'Università de Macerata 47, 52-53, Macerata.

CALDERone, S., 1993: "Costantinopoli: la «seconda Roma»"», en A. Momigliano y A. Schiavone (a cura di), Storia di Roma 3. L'età tardoantica I. Crisi e trasformazioni, 723-749, Torino.

CAndau Morón, J.M., 1990: «Providencia y política en los historiadores paganos de la Baja Antigüedad», en J.M. Candau Morón, F. Gascó la calle y Ramírez A. De Vergue (eds.), La conversión de Roma. Cristianismo y paganismo, 191-210, Madrid.

CASSIN, E., 1951: «Daniel dans la «fosse» aux lions», Revue de l'Histoire des Religions, 139, 129-161.

Cristofoli, R., 2005: Costantino e l'Oratio ad Sanctorum coetum, Napoli.

DAGRON, G., 1974: Naissance d'une capitale: Constantinople et ses institutions de 330 à 451, Paris.

Dalton, O.M., 1901: Catalogue of Early Christian Antiquities and objects from the Christian East of the British Museum, London.
DANiÉLOU, J., 1957: «Daniel», en Th. Klauser y E. Dassmann (eds.), Reallexikon für Antike und Christentum. Sachworterbuch zur Auseinandersetzung des Christentums mit der antiken Welt, I, 575-585, Stuttgart.

DelCor, M., 1986: «La prophétie de Daniel (chap. 2 et 7) dans la littérature apocalyptique juive et chrétienne en référence spéciale à l'empire romain», en P. Catalano y P. Siniscalc (eds.), Atti del I Seminario internazionale di studi storici Da Roma alla terza Roma. Popoli e spazio romano tra diritto e profezia, 11-24, Napoli.

DÉONNA, W., 1948: «Les lions attachés à la colonna», Mélanges Ch. Picard, 289-308.

DÉONNA, W., 1949: «Daniel, le maître des fauves», Artibus Asiae, X, 4, 119-140.

DE Rossi, G.B., 1887: «Statua del buon pastore scoperta in Roma presso la porta Ostiense», en Ibíd.: Bulletino di Archeologia Cristiana, s. I, a. V, Roma.

DöRRIES, H., 1954: Das Selbstzeugnis Kaiser Konstantins, Göttingen.

DRAKE, H.A., 1975: «When Was the De Laudibus Constantini Delivered?», Historia, 24, 347-356.

DRAKE, H.A., 1976: In praise of Constantine. A Historical Study and New translation of Eusebuis' Tricennal Orations, Berkeley-Los Angeles-London.

EUSĖBE DE CÉSARÉE, 2001: La théologie politique de l'Empire Chrétien. Louanges de Constantin (Triakontaétérikos), ed. de P. Maraval, Paris.

Eusebio De Cesarea, 1994: Vida de Constantino, ed. de M. Gurruchaga, Madrid.

Eusebio Di CesareA, 1984: Sulla Vita di Costantino, ed. de L. Tartaglia, Napoli.

Eusebius, 1999: Life of Constantine, ed. de A. Cameron y G. Hall, Oxford.

FARINA, R., 1966: L'Impero e l'Imperatore cristiano in Eusebio de Cesarea. La prima teologia politica del Cristianesimo, Zürich.

FIRALTI, N., 1990: La sculpture byzantine figurée au Musée Archéologique d'Istanbul, Paris.

FLORIANI SQUARCIAPINO, M., 1941: «Un gruppo di Orfeo tra le fiere del Museo di Sabratha», Bullettino della Commissione Archeologica del Governatorato di Roma, L, 61-79.

FLORIANI SQUARCIAPINO, M., 1946-48: "A proposito del candelabro di Byblos», Bullettino della Commissione Archeologica Comunale di Roma, 72, 9-15.

FLuSSER, D., 1972: «The Four Empires in the Fourth Sybil and in the Book of Daniel», Israel Oriental Studies, 2, 148-175.

GASCÓ LA CALLE, F., 1981: «La teoría de los cuatro imperios. Reiteración y adaptación ideológica. I. Romanos y griegos», Habis, 12, 179-196.

GigLIOLI, C.G., 1952:LacolonnadiArcadio a Costantinopoli, Memorie dell'Accademia di Archeologia, lettere e Belle arti di Napoli, 2, Napoli.

GINZBURG, C., 1981: Indagini su Piero: il Battesimo, il ciclo di Arezzo, la Flagellazione di Urbino, Torino.

GRIGG, R., 1977: «Constantine the Great and the Cult without Images», Viator, 8, 1-32.

GrossetT, Ch., 1953: «L'origine du thème romain de Daniel», Études Mérovingiennes, 147-156. 
HEIKEL, I.A. (ed.), 1902: Eusebius Werke 1, Grieschischen Christlichen Schriftsteller der Ersten Jahrhunderte 7, Leipzig.

HeIKEL, I. (ed.), 1913: Eusebius Werke V. Grieschischen Christlichen Schriftsteller der Ersten Jahrhunderte 23, Leipzig.

JANIN, R., 1950: Constantinople Byzantine. Développement urbain et répertoire topographique, Paris.

KENT, J.P.C., 1978: Roman Coins, London.

KLAuSER, Th., 1965: «Die Aüserungen der alten Kirche zur Kunst», in Atti del V congresso internazionale di Archeologia Cristiana (Ravenna, 23-30 settembre 1962), 223242, Roma.

KollwITZ, J., 1953: «Zur Frühgeschichte der Bilderverehrung», Römische Quartalschrift für Christliche Altertumskunde und Kirchengeschichte, 48, 1-20.

LA RoccA, E.: «La fondazione di Costantinopoli», in G. Bonamente y F. Fusco (eds.), Costantino il Grande. Dall'Antichità all'umanesimo I, 553-583, Macerata.

LAUFFRAY, I., 1940: «Une fouille au pied de l'Acropole de Byblos», Bulletin Du Musée de Beyrouth, I, 7-36.

LECLERCQ, H., 1920: «Daniel», en F. Cabrol y H. Leclercq (eds.), Dictionnaire d'Archéologie Chrétienne et de la Liturgie, I, 1, 223, Paris.

Mango, C., 1959: The Brazen house. A study of the vestibule of the Imperial Palace of Constantinople, Københarn.

MANGO, C., 1985: Le développment urbain de Constantinople (Ie-Ve siècles), Paris.

MAURICE, J., 1908-1912: Numismatique constantinienne, Paris.

Mendel, G., 1914: Catalogue du Musée de Constantinople (Catalogue des sculptures grecques, romaines et byzantines) I, Constantinople.

MenichetTI, M., 1994: Archelogia del potere. Re, immagini e miti a Roma e in Etruria in età arcaica, Milano.

Minasi, M., 2000: «Daniele», en F. Bisconti (ed.), Temi di iconografia paleocristiana, 162-164, Città del Vaticano.

Momigliano, A., 1987: «Daniele e la teoria greca della successione degli imperi», en Ibid.: Storia e storiografia antica, 39-46, Bologna.

NASRALLAH, J., 1961: «Bas-reliefs chrétiens inconnus de Syrie», Syria, 38, 35-53.

PAVAN, M., 1986: «Le profezie di Daniele e il destino di Roma negli scrittori latini dopo Costantino», en P. Catalano y P. Siniscalco (eds.), Atti del I Seminario internazionale di studi storici Da Roma alla terza Roma. Popoli e spazio romano tra diritto e profezia, 298-308, Napoli.
PICARD, C., 1947: «Sur l'Orphée de la Fontaine monumentale de Byblos», Orientalia Christiana Periodica, X, Miscellanea G. De Jerphanion, I, 266-281.

PICCINI, P., 1993: «Ideologia e storia in termini del lessico politico eusebiano: il tempo eterno della Basileia di Costantino», en Bonamente, G. y Fusco, F. (eds.), Costantino il Grande. Dall'antichità all'umanesimo. Colloquio sul Cristianesimo nel mondo antico (Macerata 18-20 Dicembre 1990), t. I, 769-790, Macerata.

PIZZANI, U., 1993: «Costantino e l'Oratio ad Sanctorum coetum», en G. Bonamente y F. Fusco (eds.), Costantino il Grande. Dall'Antichità all'umanesimo, t. I, 791-822, Macerata.

PODSKALSKY, G., 1984: «Répresentation du temps dans l'eschatologie impériale byzantine», en AA.VV.: Le temps chrétien de la fin de l'Antiquité au Moyen Age IeXe siècles (Colloques internationaux du C.N.R.S., 604), 439-450, Paris.

Pugliese CARratelli, G., 1981: «L'imitatio Alexandri costantiniana», Felix Ravenna, 118, 81-91.

SCHIAVONE, A., 1998: La storia spezzata. Roma antica e occidente moderno, Bari.

SetTIS, S., 1978: La tempesta interpretata. Giorgione, $i$ committenti, il soggetto, Torino.

SeuX, M.-J. (ed.), 1976: Hymnes et Prieres aux dieux de Babylonie et d'Assyrie, Paris.

SimONETTI, M., 1986: «L'esegesi patristica di Daniele 2 e 7 nel II e III secolo», en P. Catalano y P. Siniscalco (eds.), Atti del I Seminario internazionale di studi storici Da Roma alla terza Roma. Popoli e spazio romano tra diritto e profezia, 37-47, Napoli.

SwaIn, J.W., 1940: «The Theory of Four Monarchies. Opposition History Under the Roman Empire», Classical Philology, 35, 1-21.

TORELli, M., 1997: Il rito, il rango e l'immagine. Alle origini della rappresentazione storica romana, Milano.

TSAFRIR, Y., 1989: "Christian archaeology in Israel in recent years», in Actes du Xe Congrès International d'Archéologie Chrétienne 2, 1739-1740, Roma.

WinkelmanN, F., 1962: «Zur Geschichte des Authenzitätsproblems der Vita Constantini», Klio, 40, 187-243.

WIXOM, W.D., 1967: «Early Christian Sculptures at Cleveland», Bulletin of the Cleveland Museum of Art, L, $67-88 \mathrm{k}$.

WulfF, O., 1909: Altchristliche und Mittelalterliche Byzantinische Und Italienische Bildwerke, Berlin.

ZANKER, P., 1992: Augusto y el poder de las imágenes, Madrid.

ZANKER, P., 2002: Un'arte per l'Impero. Funzione e intenzione delle immagini nel mondo romano, Milano. 